\title{
Penggunaan Media Sosial sebagai Sarana Kampanye dan Partisipasi Digital dalam Pilkada Kota Depok Tahun 2020
}

\author{
Wildhan Khalyubi ${ }^{1}$, Christian Deswinta Bangun², Fikri Ardiyansyah³, Muhammad Rifqi \\ Romadhona ${ }^{4}$ \\ 1, 2, 3 Universitas Indonesia, Jl. Prof. Dr. Selo Soemardjan, Depok \\ 4 Universitas Pertahanan, Komplek Indonesia Peace and Security Center (IPSC) Sentul, Bogor \\ Corresponding Author: wildhan.khalyub@gmail.com
}

\section{Keyword: \\ Social Media;}

Digital Participation;

Conccurent Local

Election
Kata Kunci:

Media Sosial;

Partisipasi Digital;

Pilkada Serentak

\begin{abstract}
This study aims to explain the phenomenon of political campaign and form of digital participation through the use of social media such as Facebook and Twitter in the Conccurent Local Election in 2020. This study focuses on Depok City by looking at the social media of each candidate pair for Conccurent Local Election 2020 in Depok City between Pradi-Afifah and Idris-Imam. The approach in this study uses a qualitative approach involving campaign issues on social media and form of digital participation. Some of the data in this study were obtained from monitoring findings regarding candidate pairs' campaigns through conversational narratives on social media at the Depok City Election 2020 campaign stage. Narratives of campaign issues on social media were obtained using Social Network Analysis (SNA). The findings in this study indicate that in the use of social media, each pair of candidates has different preferences for campaign issues. Although the candidate pairs have dominant campaign issues and very high digital participation, this does not necessarily become a determining factor in winning the contestastion of 2020 Local Election in Depok City.
\end{abstract}

\begin{abstract}
Abstrak: Penelitian ini bertujuan untuk menjelaskan fenomena politik kampanye dan bentuk partisipasi digital melalui penggunaan media sosial seperti Facebook dan Twitter pada penyelenggaraan Pilkada Serentak 2020. Penelitian ini berfokus di Kota Depok dengan melihat media sosial masingmasing pasangan calon Pilkada Kota Depok 2020 yakni antara Pradi-Afifah dan Idris-Imam. Pendekatan dalam penelitian ini menggunakan pendekatan kualitatif dengan yang melibatkan isu kampanye di media sosial beserta bentuk partisipasi digital. Beberapa data dalam penelitian ini diperoleh dari temuan pemantauan mengenai kampanye pasangan calon melalui narasi percakapan di media sosial pada tahapan kampanye Pilkada Kota Depok Tahun 2020. Narasi isu kampanye di media sosial diperoleh menggunakan Social Network Analysis (SNA) terutama pada media sosial Facebook dan Twitter. Temuan dalam penelitian ini menunjukan bahwa dalam penggunaan media sosial, setiap pasangan calon memiliki preferensi isu kampanye yang berbeda-beda. Kendati pasangan calon memiliki isu kampanye yang dominan serta partisipasi digital yang begitu tinggi, hal tersebut tidak serta merta menjadi faktor determinan dalam memenangkan kontestasi Pilkada Kota Depok 2020.
\end{abstract}

Informasi Artikel: Disubmit: 08-07-2021, Revisi: 26-07-2021, Diterima: 08-08-2021 


\section{PENDAHULUAN}

Mewabahnya pandemi Covid-19 mengubah berbagai aspek kehidupan terutama dalam urusan perpolitikan, ekonomi, sosial, budaya, serta pola interaksi yang sebelumnya sempat terjalin di kalangan masyarakat Indonesia (Ristyastuti \& Rofii, 2021). Perubahan aspek tersebut menjadikan penyelenggaraan pilkada serentak pada tahun 2020 menjadi pilkada dengan pengalaman pertama dalam keadaan pandemi Covid-19. Hal ini dikarenakan agenda pemilu maupun pilkada di Indonesia belum diatur penyelenggaraannya dalam situasi bencana melalui undang-undang, baik itu bencana alam ataupun bencana non-alam. Keterjaminan mengenai keamanan dan keselamatan seluruh aspek dalam hal ini penyelenggara, peserta, dan pemilih menjadi hal yang utama dalam gelaran Pilkada Serentak Tahun 2020.

Tahapan penyelenggaraan Pemilihan Kepala Daerah (Pilkada) yang sempat tertunda karena pandemi Covid-19 menemukan kepastian untuk dilanjutkan. Alasan mengenai keberlanjutan pilkada tersebut salah satunya dikarenakan bahwa pilkada merupakan agenda yang akan menciptakan pejabat definitif yang memiliki legitimasi dan kewenangan penuh untuk menjalankan pemerintahan dan kebijakan strategis termasuk dalam penanganan pandemi Covid-19 yang belum jelas kapan akan berakhirnya (Baroya, 2020). Ketetapan kelanjutan penyelenggaraan pilkada tersebut diputuskan dalam Rapat Kerja dan Rapat Dengar Pendapat Komisi II DPR RI pada tanggal 27 Mei 2020 bersama beberapa pihak antara lain Kementrian Dalam Negeri, Komisi Pemilihan Umum (KPU), Badan Pengawas Pemilu (Bawaslu), dan Dewan Kehormatan Penyelenggara Pemilu (DKPP). Lebih lanjut, keputusan itu diperkuat dengan adanya Surat Ketua Gugus Tugas Nomor B 196/KA GUGAS/PD.01.02/05/2020 yang dikirimkan kepada KPU dengan berisikan beberapa poin penting untuk melaksanakan kelanjutan Pilkada Serentak 2020 (Kumparan, 2020). Ada pun, beberapa poin tersebut ialah pertama, mengapresiasi seluruh stakeholder dalam membuat keputusan kelanjutan Pilkada pada Desember 2020. Kedua, menghormati terbitnya peraturan pemerintah pengganti undangundang (Perppu) Nomor 2 Tahun 2020 terkait penundaan Pilkada. Dan ketiga memberikan saran serta masukan kepada KPU RI untuk melanjutkan Pilkada dengan bersandar pada Perppu Nomor 2 Tahun 2020 pasal 201A, terkait syarat dilaksanakan dengan penggunana protokol kesehatan penanganan Covid-19 pada setiap tahapan penyelenggaraan Pilkada (Kompas, 2020).

Keberlanjutan dari tahapan pelaksanaan Pilkada membutuhkan sebuah manajemen resiko (Electoral Risk Management) sebagai jaminan bahwa pelaksanaan pemilihan atau pemilu dapat menjamin seluruh warga negara ikut serta berpartisipasi (Alihodžić, 2016; Sakbani, 2020). Di sisi lain, manajemen resiko dalam pemilihan kepala daerah juga dapat berpengaruh dengan dijadikan sebagai indikator pencapaian proses penyelenggaraan, terutama segala hal yang menyangkut dengan keterlindungan hak pilih warga negara. International IDEA dalam (Alihodžić, 2016) menjelaskan bahwa manajemen risiko pemilu merupakan upaya sistematis yang perlu dilakukan dengan memadukan pengetahuan kesadaran situasional terhadap risiko internal dan eksternal yang dapat berpengaruh terhadap proses pemilu guna menciptakan tindakan pencegahan dan mitigasi yang tepat waktu. Lebih lanjut, beberapa langkah mengenai manajemen risiko tersebut dijelaskan oleh International IDEA seperti identifikasi risiko, pengukuran risiko, pelaporan, dan pembuatan keputusan (Purbolaksono, 2021). Beberapa langkah mengenai manajemen resiko tersebut merupakan tolak ukur bagi penyelenggaraan pilkada di tengah pandemi Covid-19. Maka dari itu, menimbang putusan serta saran dari Gugus Tugas di atas tersebut, KPU RI mengeluarkan surat keputusan Nomor 258/PL.02Kpt/01/KPU/VI/2020 tentang Penetapan Pelaksanaan Pilkada Serentak Lanjutan Tahun 2020. Tahapan lanjutan tersebut dimulai pada tanggal 15 Juni 2020 dengan pelantikan dan masa kerja para petugas ad-hoc yang sebelumnya sempat tertunda.

Keberlanjutan pilkada di tengah pandemi Covid-19 tidak hanya diselenggarakan di Indonesia. Terdapat beberapa negara yang juga melanjutkan agenda pemilu di tengah pandemi Covid-19. Misalnya Korea Selatan yang merupakan salah satu negara melanjutkan penyelenggaraan pemilu di tengah pandemi Covid-19. Kesuksesan penyelenggaraan pemilu di Korea Selatan didukung dengan manajemen resiko pemilu. Terutama memiliki pengalaman menghadapi virus MERS (Middle East Respiratory Syndrome) pada tahun 2015 dan 2018. Hal tersebut menjadi katalisator penyelenggaraan pemilu di tengah pandemi Covid-19. Kesiapan 
institusional yang dibekali dengan sistem pengendalian epidemi yang terlembaga dalam undang-undang, kerja sama antar pemerintah, unit perawatan intensif, dan lain sebagainya menjadi alasan dibalik keberhasilan Korea Selatan menekan penyebaran Covid-19. Ini juga menjadi jaminan melanjutkan agenda pemerintahan yakni pemilu (Kim, 2020).

Selain itu, Singapura juga menjadi salah satu negara yang melanjutkan pemilu di tengah pandemi Covid-19. Konsekuensi diadakannya pemilu di tengah pandemi berimplikasi pada pengaturan teknis pemilu yang diperketat terutama di saat kampanye yang lebih banyak menggunakan media sosial hingga pengaturan waktu saat memilih di bilik suara (RNZ, 2020). Kedua negara tersebut merupakan gambaran bagaimana penyelenggaraan pemilu di tengah pandemi Covid-19. Implikasinya ialah bagaimana pengaturan seluruh tahapan pemilihan memuat manajemen resiko pemilu terutama kepastian pengaturan yang lebih ketat mengenai protokol kesehatan dan juga pengaturan teknis yang dianggap alternatif terhadap situasi pandemi.

Adapun pengaturan mengenai kampanye dalam Peraturan Komisi Pemilihan Umum (PKPU) menjadi salah satu peraturan yang memperhatikan dampak dari terjadinya wabah Covid-19 terhadap regulasi Pilkada. Pengaturan Kampanye di Pilkada 2020 terdapat pada PKPU No. 13 Tahun 2020 tentang Perubahan Kedua atas Peraturan Komisi Pemilihan Umum Nomor 6 Tahun 2020 tentang Pelaksanaan Pemilihan Gubernur dan Wakil Gubernur, Bupati dan Wakil Bupati, dan/atau Wali Kota dan Wakil Wali Kota Serentak Lanjutan dalam Kondisi Bencana Nonalam Corona Virus Disease 2019 (Covid-19). Tepatnya Pasal 58 pada PKPU tersebut merupakan salah satu ketentuan yang diubah dari PKPU sebelumnya yang menyebutkan bahwa Partai Politik atau Gabungan Partai Politik, Pasangan Calon, Tim Kampanye, dan/atau pihak lain mengutamakan metode Kampanye pertemuan terbatas dan pertemuan tatap muka dan dialog sebagaimana dimaksud dalam Pasal 57 huruf a dan huruf b dilakukan melalui Media Sosial dan Media Daring.

Klausul dalam PKPU tersebut menjelaskan bahwa media sosial menjadi salah satu bentuk alternatif dalam hal penyampaian kampanye oleh peserta Pilkada terhadap masyarakat. Penyampaian informasi yang memuat segala perihal substantif dalam proses kampanye, sedikit disandarkan pada media sosial. Namun, ini juga memperlihatkan bahwa bentuk akses terhadap informasi kampanye tersebut tergantung pada warga internet selaku pengguna media sosial. Apakah kampanye yang dinarasikan di media sosial dapat membangun ketertarikan hingga respon dari warga internet, atau bahkan menjadi sebaliknya. Penelitian ini berlokasi di Kota Depok dengan terdapat beberapa alasan yang juga turut mendasari. Pertama, Kota Depok merupakan daerah ketika adanya temuan kasus pertama Covid-19. Kedua, Kota Depok juga merupakan salah satu daerah yang menyelenggarakan Pilkada di Jawa Barat beserta dengan 7 daerah lainnya seperti Kabupaten Bandung, Cianjur, Sukabumi, Karawang, Indramayu, Tasikmalaya, dan Pangandaran. Sehingga penelitian ini melihat dua sisi yang saling terintegrasi antara penyelenggaraan Pilkada dengan pandemi Covid-19 di Kota Depok.

Fenomena pengaturan kampanye yang berubah pada penyelenggaraan pilkada, secara tidak langsung mempertanyakan ulang mengenai definisi kampanye. Beberapa ilmuwan sebelumnya telah mengulas pandangan mengenai definisi kampanye tersebut. Misalnya pandangan terdahulu seperti Paisley \& Rice (1981) mendefinisikan kampanye sebagai keinginan untuk memengaruhi kepercayaan dan tingkah laku orang lain dengan daya tarik yang komunikatif. Serupa dengan pandangan tersebut, Roger \& Storey (1987) yang menjelaskan kampanye merupakan sebuah tindakan komunikasi terencana dengan memiliki tujuan untuk menimbulkan efek tertentu terutama pada sejumlah besar khalayak yang dilakukan secara berkesinambungan pada kurun waktu tertentu. Kedua pandangan terdahulu mengenai kampanye tersebut menjelaskan terkait adanya pengaruh atau efek tertentu terhadap penerima pesan. Selain itu, pandangan Dan Nimmo (2010) juga kemudian menjelaskan terkait keberlanjutan pengaruh terhadap penerima kampanye politik. Dan Nimmo (2010) menjelaskan bahwa orang yang paling banyak diterpa komunikasi persuasif kampanye adalah yang paling cenderung telah sampai kepada putusan pemberian suara; dalam hal ini yang paling besar kemungkinannya ialah dipengaruhi oleh imbauan persuasif ialah yang paling sedikit minatnya 
terhadap politik dan, karena itu, paling sedikit kemungkinannya memerhatikan komunikasi kampanye.

Beberapa pandangan di atas mengenai kampanye tidak menjelaskan lebih lanjut bentuk kampanye yang kerap dilakukan di media sosial. Beberapa tahun terakhir kehadiran teknologi informasi mengubah model kampanye politik yang biasanya dilakukan secara tradisional namun kini dapat dilakukan secara digital terutama melalui media sosial. Pandangan Hagar (2014) mengenai kampanye politik secara digital di media sosial ini dapat berkontribusi terhadap keberhasilan politik dikarenakan media sosial membuat kandidat dapat berinteraksi dengan para calon pemilih melalui intentsitas yang tak dapat diwujudkan melalui kampanye secara tradisional sebelumnya. Kemudian Chester \& Montgomery (2017) memperkuat argumentasi mengenai penggunaan media sosial dalam berkampanye dengan menjelaskan faktor kecanggihan pasar digital yang juga berdampak pada meningkatnya kapasitas dan bentuk kampanye politik dalam menjangkau dan berinteraksi antara kandidat dan pemilih. Lebih lanjut kehadiran media sosial menawarkan interaktivitas yang tidak ditawakan oleh media konvensional seperti televisi dan radio, sehingga interaktivitas ini sejalan dengan konsep demokrasi (Andriadi, 2017). Masyarakat dapat mengakses informasi dengan mudah hingga berpartisipasi dengan komentar dikarenakan ada aktivitas dua arah pada media sosial memunculkan partisipasi politik di media sosial.

Beberapa pandangan tersebut coba penulis lengkapi dengan pandangan kampanye politik di media sosial oleh Pandangan Michael J. Jansen (2017) dalam literaturnya yang berjudul Social Media and Political Campaigning: Changing Terms of Engagement?. Michael J. Jansen (2017) menjelaskan bahwas platform media sosial merupakan bentuk revolusioner dengan turut menciptakan ruang komunikasi horizontal di dalam kampanye politik yang hierarkis. Terdapat tiga alasan menurut Michael J. Jansen (2017) terkait penggunaan media sosial sebagai alat kampanye dan mengubah bentuk kampanye beserta keterlibatan penggunanya. Pertama, kampanye di media sosial membentuk komunikasi berbentuk responsif yang nantinya dapat membentuk legitimasi pilihan komunikatif seperti membahas problematika, isu kampanye dan juga topik tertentu pada kampanye tersebut. Kedua, dengan adanya beberapa fitur di media sosial, kampanye yang dilakukan dapat membentuk transmisi ulang pesan kampanye yang disebarluaskan atau diunggah kembali melalui komunikasi yang dihasilkan oleh para pendukung. Transmisi ulang pesan politik tersebut dapat mendiskusikan dan mendefinisikan topik atau permasalahan tertentu. Ketiga, penggunaan media sosial sebagai alat berkampanye dapat mengundang orang yang merupakan pengguna media sosial itu sendiri untuk berpartisipasi secara tidak struktur di media sosial. Ketidakstrukturan bentuk kampanye tersebut merupakan konsekuensi logis dari adanya hubungan para pengguna media sosial berdasarkan retorika narasi kampanye di media sosial tersebut.

Namun, penggunaan media sosial dalam hal kampanye Pilkada di Kota Depok melalui temuan di lapangan oleh Bawaslu Kota Depok juga dinilai belum menunjukan efektivitas penyampaian narasi mengenai isu kampanye. Hal tersebut dijelaskan dalam temuan Bawaslu Kota Depok hingga 5 November 2020 bahwasannya perbandingan kampanye daring di media sosial dan kampanye tatap muka begitu jauh jumlahnya. Kampanye pasangan calon nomor urut 1, Pradi-Afifah, memiliki jumlah kampanye tatap muka dan pertemuan terbatas sebanyak 239 pertemuan berbanding dengan kampanye daring yang hanya 1 kali dilakukan. Sementara itu, pasangan calon nomor urut 2, Idris-Imam, memiliki jumlah kampanye tatap muka dan pertemuan terbatas sebanyak 596 pertemuan berbanding dengan kampanye daring yang sebesar 15 kali dilakukan (tabel 1). Dalam temuan tersebut juga menunjukan bahwa masingmasing pasangan calon memiliki pelanggaran protokol kesehatan yang hampir sama dalam tahapan kampanye. Dimana pasangan calon nomor urut 1 memiliki 12 pelanggaran, dan pasangan calon nomor urut 2 memiliki 11 pelanggaran (Permana, 2020). 
Tabel I. Data Satu Bulan Penagwasan Kampanye Bawaslu Kota Depok

\begin{tabular}{|l|c|c|c|}
\hline \multicolumn{1}{|c|}{ Kontestan } & $\begin{array}{c}\text { Kampanye Tatap } \\
\text { Muka dan } \\
\text { Pertemuan } \\
\text { Terbatas }\end{array}$ & $\begin{array}{c}\text { Kampanye } \\
\text { Daring }\end{array}$ & $\begin{array}{c}\text { Pelanggaran } \\
\text { Protokol } \\
\text { Kesehatan }\end{array}$ \\
\hline Pasangan Calon 1 & 239 & 1 & 12 \\
(Pradi-Afifah) & 596 & 15 & 11 \\
\hline Pasangan Calon 2 & & & \\
\hline
\end{tabular}

Sumber: Siaran Pers Bawaslu Kota Depok Satu Bulan Pengawasan Kampanye pada tanggal 5 November 2020

Lebih lanjut, temuan tersebut menuntut Bawaslu Kota Depok untuk mengirimkan 18 surat peringatan protokol kesehatan masing-masing 9 untuk tim kampanye paslon 1 dan 9 untuk tim kampanye paslon 2. Ada pun isi mengenai surat peringatan tertulis terhadap pelanggaran prokes kampanye ialah 1) tidak menjaga jarak; 2) Peserta melebihi 50 orang; dan 3) tidak menggunakan masker. Sementara itu Bentuk kampanye yang diperbolehkan di masa pandemi yakni tatap muka terbatas maksimal 50 orang, adanya potokol kesehatan, dan menggunakan daring. Hal itu tertuang dalam PKPU No. 13 Pasal 57 meliputi pertemuan terbatas, pertemuan tatap muka dan dialog, debat publik, pemasangan APK, penyebaran bahan kampanye, iklan kampanye, dan kegiatan lain yang tidak melanggar Undang-undang (Permana, 2020).

Temuan Bawaslu Kota Depok tersebut menunjukan bahwa adanya gap empiris dalam melakukan kampanye pada Pilkada 2020 di Kota Depok. Kendati pengaturan kampanye melalui media sosial dianggap sebagai alternatif atas mewabahnya Covid-19, namun para peserta Pilkada tetap melakukan tatap muka dan pertemuan terbatas saat kampanye. Sehingga penelitian ini bertujuan untuk menjelaskan fenomena politik kampanye dengan melihat bagaimana isu kampanye yang dinarasikan melalui penggunaan media sosial seperti Facebook dan Twitter pada penyelenggaraan Pilkada Serentak 2020. Penelitian ini berfokus di Kota Depok dengan melihat media sosial masing-masing pasangan calon Pilkada Kota Depok 2020 yakni antara Pradi-Afifah dan Idris-Imam.

Isu kampanye menjadi salah satu variabel dalam pandangan Michael J. Jansen (2017) dalam penggunaan media sosial sebagai alat berkampanye. Sehingga melalui isu kampanye tersebut diharapkan dapat menjadi katalisator partisipasi politik. Adapun beberapa pandangan terdahulu mengenai partisipasi politik banyak dijelaskan oleh para ilmuwan politik seperti Mirriam Budiardjo (2008) yang menjelaskan garis besar dari bentuk partisipasi politik yakni turut serta secara aktif dalam segala kehidupan politik baik oleh individu ataupun kelompok. Ataupun Ramlan Surbakti (2010) yang juga menjelaskan bentuk partisipasi politik yang digambarkan dengan ikut serta warga negara dalam proses pembuatan hingga pelaksanaan sebuah keputusan.

Namun pandangan tersebut belum begitu mewakili partisipasi politik di media sosial seiring dengan masifnya penggunaan media sosial sebagai alat kampanye. Sehingga secara tidak langsung, media sosial juga turut membentuk model baru partisipasi politik. Pandangan Theocharis (2015) berpendapat bahwa partisipasi politik saat ini harus memperhitungkan keterjangkauan platform digital seperti situs jejaring sosial. Partisipasi politik dalam dunia digital tersebut haruslah memiliki tujuan mempengaruhi kesadaran politik, sikap, keputusan, dan tindakan orang lain. Secara singkat, Theocharis (2015) menjelaskan bahwa partisipasi online, secara umum, telah didefinisikan sebagai pembuatan dan berbagi konten di internet yang ditujukan pada audiens tertentu dan didorong oleh tujuan sosial. Lebih lanjut, argumentasi mengenai implikasi media sosial terhadap partisipasi politik juga dikemukakan oleh Lee (2017) yang menjelaskan bahwa media sosial sebagai teknologi informasi baru dapat memberikan 
penjelasan mengenai kontur mobilisasi secara offline. Hal ini dikarenakan penggunaan media sosial memberikan keuntungan dari kapasitas teknologi dalam bentuk interaksi sosial yang membekali keterlibatan politik melalui diskusi antar pribadi. Secara singkat, pandangan Lee (2017) menjelaskan bahwa teknologi dapat memperluas jaringan pribadi untuk terhubung secara sosial di dunia nyata. Terciptanya sebuah keterkaitan antara dunia offline dan juga online dikarenakan masyarakat dalam keterlibatan politiknya tidak dapat dipisahkan terutama dalam peredaran sebuah informasi (Vaccari et al., 2013; Kholid \& Nurmandi, 2015).

Namun, pandangan mengenai partisipasi dalam media sosial tersebut coba penulis lengkapi dengan pandangan Lilleker \& Koc-Michalska (2017) dalam literaturnya yang berjudul What Drives Political Participation? Motivations and Mobilization in a Digital Age. Literatur tersebut menjelaskan bahwa interaksi sikap terhadap tindakan partisipatif merupakan rangkaian lebih lanjut dari adanya komunikasi persuasi. Paparan informasi yang tidak disengaja melalui platform digital dapat menyebabkan kecenderungan yang lebih tinggi untuk terlibat secara sipil. Pandangan ini serupa dengan pandangan Michael J. Jansen (2017) sebelumnya bahwa media sosial dapat mengundang orang untuk berpartisipasi secara tidak terstruktur. Hanya saja pandangan Lilleker \& Koc-Michalska (2017) memperdalam bentuk partisipasi tersebut dengan paparan informasi di media sosial dapat menimbulkan perasaan positif atau keberpihakan yang sama terhadap organisasi kampanye yang membangun komunikasi persuasi tersebut. Keberpihakan yang sama menggiring bentuk partisipasi secara digital ke dalam bentuk partisipasi secara riil di dunia nyata atau dapat memobilisasi masa secara langsung karena organisasi kampanye menyediakan jalan menuju partisipasi politik secara riil melalui upaya secara retorik di dunia maya. Sehingga dapat dikatakan bahwa partisipasi politik secara digital di dunia maya dapat semakin menumbuhkan berbagai bentuk partisipasi politik di dunia nyata.

Partisipasi politik merupakan sebuah jantung dari demokrasi. Keduanya tidak dapat dipisahkan, melainkan partisipasi politik merupakan indikator untuk melihat demokrasi di sebuah negara tersebut (Rusnaedy \& Purwaningsih, 2018 dan Rusnaedy, 2020). Kewarganegaraan secara online justru tidak menghambat gaya partisipasi politik konvensional yang ada terlebih dahulu. Partisipasi digital bukan merupakan titik akhir dari bentuk partisipasi itu sendiri, melainkan partisipasi digital dapat mendorong bentuk partisipasi yang lebih besar dengan berbagai pengaturannya. Terutama dalam melihat bentuk kampanye di media sosial, partisipasi digital dapat dijadikan indikator mengenai keberpihakan dan respon warga internet terhadap setiap legitimasi bentuk komunikasi politik akun media sosial yang merepresentasikan pasangan calon tersebut.

Pandangan Michael J. Jansen (2017) yang menjelaskan bahwa media sosial merupakan bentuk revolusioner dalam kampanye politik dipilih sebagai pendangan utama untuk menunjukan realitas dari penelitian ini. Terutama pandangan Michael J. Jansen (2017) yang menjelaskan bahwa kampanye di media sosial dapat menciptakan legitimasi komunikasi politik berupa pembahasan mengenai permasalahan sosial, isu kampanye dan lain sebagiannya. Namun dalam menjelaskan realitas isu kampanye yang dinarasikan di media sosial tersebut, pemahaman mengenai narasi organisasi kampanye yang mewakili pasangan calon selaku aktor politik melalui akun media sosial coba dipertajam oleh penulis melalui temuan penelitian ini. Sehingga dibutuhkan dukungan pandangan utama mengenai isu kampanye di media sosial sebagai tolak ukur terhadap isu kampanye tersebut. Konsep partisipasi digital menurut Lilleker \& Koc-Michalska (2017) memperdalam bentuk partisipasi yang menjelaskan bahwa paparan informasi di media sosial dapat menimbulkan perasaan positif atau keberpihakan yang sama dengan organisasi kampanye yang membangun komunikasi persuasif tersebut. Partisipasi secara online tersebut dapat juga diwujudkan secara offline termasuk memobilisasi warga internet untuk memilih salah satu pasangan calon. Pandangan ini merupakan pandangan yang memperjelas indikator untuk melihat ketertarikan warga internet terhadap isu kampanye di media sosial yang diutarakan oleh setiap pasangan calon.

Penelitian ini mencoba untuk menunjukan kebaruan dalam optimalisasi kampanye menggunakan media sosial dengan melihat perbandingan isu kampanye yang sering dinarasikan oleh masing-masing pasangan calon di Kota Depok. Urgensi dari penelitian ini ialah 
belum ada penelitian yang mengukur efektivias penggunaan media sosial dalam berkampanye yang dijadikan sebagai salah satu faktor penentu sebagai salah satu strategi pemenangan kontestasi pemilihan. Bentuk partisipasi politik secara digital dilihat dari respon warga internet. sehingga penelitian ini menunjukan isu kampanye yang memang dapat menarik atensi warga internet dengan melihat jumlah partisipasi politik dalam bentuk respon komentar di media sosial pada Pemilihan Kepala Daerah Kota Depok Tahun 2020. Argumentasi awal penulis dalam penelitian ini ialah kendati salah satu pasangan calon memiliki isu kampanye yang dominan serta dapat mengoptimalkan penggunaan media sosial dengan menarik keterlibatan dalam partisipasi politik yang begitu tinggi, hal ini tidak serta merta dapat dijadikan sebagai faktor kemenangan pada pemilihan kepala daerah Kota Depok Tahun 2020.

\section{METODE PENELITIAN}

Metode penelitian ini adalah deskriptif kualitatif dengan studi komparasi pada literatur dan juga percakapan narasi isu kampanye Pilkada Kota Depok di media sosial. Pendekatan kualitatif merupakan pendekatan yang didalamnya menerapkan metode-metode untuk mengeksplorasi dan memahami makna yang -oleh sejumlah individu atau sekelompok orangdianggap berasal dari masalah sosial atau kemanusiaan (Creswell, 2016). Sementara itu komparasi politik diartikan sebagai upaya untuk membandingkan segala bentuk kegiatan politik, baik itu yang berkaitan dengan pemerintahan maupun yang tidak berhubungan dengan pemerintahan (Chilcote, 2016).

Penelitian ini memadukan segala aktivitas politik secara digital dengan penggunaan media sosial dalam penyelenggaraan Pilkada di tengah pandemi Covid-19 guna mengeksplorasi makna aktivitas tersebut. Penggunaan media sosial dalam menyampaikan isu kampanye dinilai merupakan upaya alternatif pada Pilkada di tengah pandemi Covid-19. Maka penelitian ini diharapkan dapat melengkapi penelitian sebelumnya terkait kampanye di media sosial. Beberapa data dalam penelitian ini diperoleh dari temuan pemantauan mengenai kampanye pasangan calon melalui narasi percakapan di media sosial pada tahapan kampanye Pilkada Kota Depok Tahun 2020. Ada pun media sosial yang diamati penulis berupa media sosial main stream seperti Facebook dan Twitter. Kedua media sosial tersebut merupakan media sosial yang juga sering digunakan di Indonesia (Cosmopolitan, 2020). Narasi di media sosial diperoleh menggunakan Social Network Analysis (SNA) pada kedua media sosial tersebut. Social Network Analysisi (SNA) merupakan studi yang mempelajari hubungan manusia dengan memanfaatkan pendekatan graph. Graph itu sendiri terbagi menjadi dua bagian yakni node yang dapat dikatakan sebagai representasi pengguna media sosial, dan edge yang dikatakan sebagai representasi relasi antar pengguna media sosial (Diana, 2017). Sementara partisipasi digital sebagai data pendukung untuk melihat isu kampanye di kedua media sosial tersebut dilihat secara manual setiap minggunya. Adapun mengenai keabsahan penelitian ini dilihat melalui narasi yang muncul di setiap media sosial baik itu yang muncul dari akun media sosial pasangan calon maupun komentar di kedua media sosial tersebut. Narasi yang muncul sebagai komentar warga internet tersebut turut diklasifikasikan ke dalam tiga respon sebagai bentuk partisipasi digital yakni positif, netral, dan negatif.

Teknik pengumpulan data dari penelitian ini dilihat melalui indikator percakapan yang muncul pada kedua media sosial tersebut. Beberapa indikator isu kampanye di Pilkada Kota Depok antara lain budaya, birokrasi, Covid-19, ekonomi, infrastruktur, isu hoax, keagamaan dan toleransi, kelompok minoritas, kesehatan, lingkungan, olahraga, pariwisata, pendidikan, perempuan, pertanian, sosial \& politik, dan teknologi. Lebih lanjut, bentuk partisipasi digital dilihat dari ketertarikan hingga respon warga internet dijadikan sebagai indikator lanjutan dalam penelitian ini. Sehingga dari beberapa isu kampanye dari percakapan di media sosial tersebut, akan didapati pasangan mana yang memiliki respon positif, negatif, ataupun netral di Facebook dan Twitter. 


\section{HASIL DAN DISKUSI}

Bagian ini berisikan beberapa temuan penulis dalam kampanye di media sosial oleh setiap pasangan calon pada Pilkada Kota Depok. Pilkada Kota Depok sendiri diikuti oleh dua kandidat pasangan calon yakni nomor urut 1 Pradi Supriatna dan Afifah Alia yang tergabung dalam Koalisi Depok Bangkit. Sedangkan pasangan nomor urut 2 yakni Mohammad Idris dan Imam Budi Hartono tergabung dalam Koalisi Tertata Adil Sejahtera. Bagian ini berisikan dua sub-pembahasan utama yakni terkait komparasi isu kampanye dan partisipasi digital melalui respon warga internet terhadap masing-masing media sosial pasangan calon.

\section{Isu Kampanye di Media Sosial}

Sebagaimana pandangan Michael J. Jansen (2017) bahwasannya komunikasi persuasif di media sosial termasuk komunikasi yang diciptakan melalui transmisi ulang, akan membentuk legitimasi komunikasi mengenai permasalahan atau isu kampanye. Maka penulis mencoba untuk mengukur presentase beragam isu kampanye yang muncul di media sosial. Ini dimaksudkan untuk melihat orientasi pasangan calon dalam kampanye politiknya. Isu kampanye yang dinarasikan di setiap postingan media sosial pada Pilkada di Kota Depok menunjukan temuan yang beragam dari setiap pasangan calon. Ini mengartikan bahwa penggunaan media sosial sangat berpengaruh dalam membangun orientasi isu para calon pemimpin di Kota Depok. Penulis mencoba melihat beberapa temuan yang tersebar di media sosial seperti Facebook dan Twitter. Grafik 1 dan Grafik 2 memperlihatkan sejumlah narasi kampanye dari setiap pasangan calon di Kota Depok berdasarkan beberapa indikator yang muncul dalam setiap penyampaiannya. Penulis menggabungkan temuan dari setiap media sosial (Facebook dan Twitter) kedalam satu grafik untuk mempermudah dalam menjelaskan temuan dari penelitian ini.

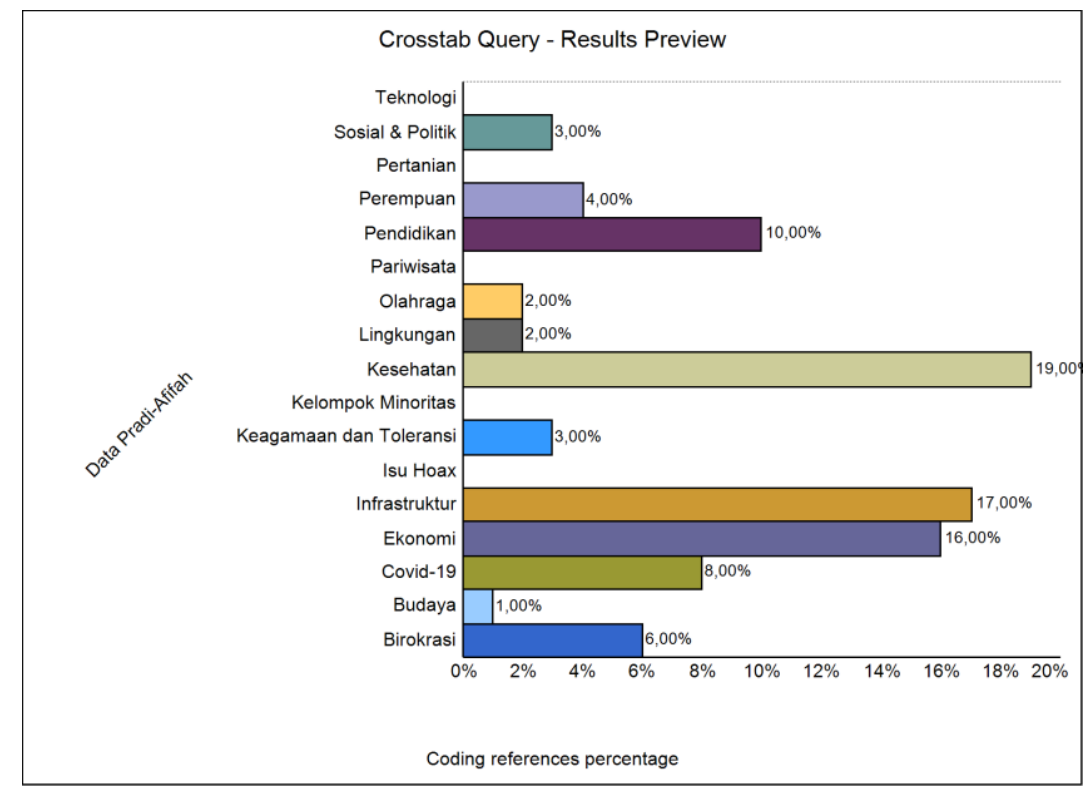

Grafik 1. Isu Kampanye Pradi-Afifah di Media Sosial Sumber: Data diolah penulis

Grafik 1 menunjukan bahwa isu kampanye pasangan Pradi-Afifah di media sosial memperlihatkan bahwa terdapat tiga orientasi isu utama yang kerap di kampanyekan. Tiga isu tersebut yakni berkaitan dengan kesehatan sebesar 19\%. infrastruktur sebesar 17\%, dan juga isu ekonomi sebesar $16 \%$. Isu kampanye terkait kesehatan yang dinarasikan di media sosial merupakan isu yang tertinggi pada pasangan calon nomor urut 1 . Isu kesehatan di media sosial yang begitu tinggi tersebut dikarenakan adanya program berobat gratis menggunakan KTP yang selalu dinarasikan di kedua media sosial tersebut. Sedangkan, isu kampanye terkait pembangunan infrastruktur di media sosial tersebut menguat dikarenakan adanya program 
pembangunan Madrasah serta tawaran solusi atas permasalahan kemacetan yang kerap dinarasikan, sehingga hal tersebut menjadi faktor yang memperkuat tingginya isu infrastruktur pada pasangan calon tersebut. Sementara kampanye mengenai isu ekonomi sebesar $16 \%$ menjadi isu kampanye tertinggi ketiga karena adanya narasi mengenai program pengembangan ekonomi program pelatihan UMKM termasuk kemudahan izin dalam membangun perekonomian di Kota Depok.

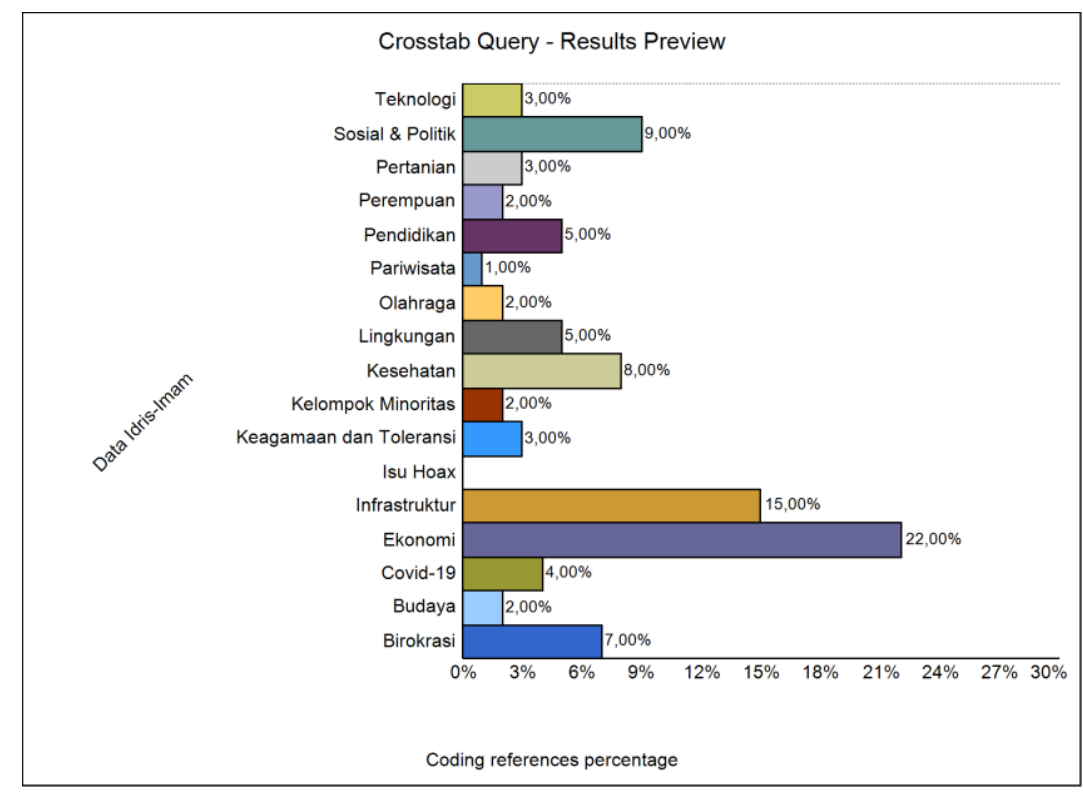

Grafik. 2 Isu Kampanye Idris-Imam di Media Sosial Sumber: Data diolah penulis

Sementara itu, isu kampanye yang dinarasikan pasangan calon nomor urut 2 di media sosial dibilang lebih merata dari pada isu kampanye pasangan calon nomor urut 1 seperti pada grafik 2. Idris-Imam selaku pasangan calon nomor urut 2, memiliki narasi kampanye di media sosial dengan isu ekonomi merupakan isu tertinggi sebesar $22 \%$. Kemudian, isu infrastruktur adalah isu kedua teratas dengan persentase sebesar 15\%. Sedangkan, isu kampanye mengenai sosial \& politik menempati urutan ketiga dengan persenaste sebesar $9 \%$. Tingginya isu ekonomi di media sosial pasangan calon nomor urut 2 dipengaruhi dari kampanye program SUKSES yang kerap dinarasikan dan menjadi salah satu program prioritas pasangan calon tersebut. Sedangkan, menguatnya isu infrastruktur juga dikarenakan terdapat tawaran program kebijakan salah satunya ialah renovasi rumah yang tidak layak huni yang ditawarkan oleh IdrisImam. Sementara itu munculnya isu sosial \& politik pada peringkat ketiga dikarenakan adanya narasi mengenai keterlibatan beberapa kelompok sosial seperti paguyuban, komunitas, dan karang taruna di Kota Depok yang berupaya memenangkan pasangan calon Idris-Imam.

Dari kedua grafik tersebut, masing-masing pasangan calon memiliki preferensi isu kampanye yang kerap dinarasikan di media sosial. Isu kampanye terkait ekonomi menjadi isu kampanye andalan yang kerap ditawarkan oleh kedua pasangan calon baik oleh Pradi-Afifah selaku pasangan calon nomor urut 1, maupun Idris-Imam selaku pasangan calon nomor urut 2. Namun, temuan dalam fenomena digital dari kedua pasangan calon tersebut menunjukan temuan terhadap preferensi isu kampanye lainnya. Isu kampanye mengenai penanggulangan Covid-19 masih kalah rendah dibandingkan dengan tiga isu utama masing-masing pasangan calon tersebut. Narasi isu kampanye terkait penanggulangan Covid-19 di media sosial masih kurang dari 10\%. Pradi-Afifah menunjukan persentase isu kampanye penanggulangan Covid-19 sebesar 8\%, dan menunjukan persentase tersebut lebih tinggi jika dibandingkan dengan IdrisImam yang hanya sebesar 4\%. Maka, sebagaimana pandangan Michael J. Jansen (2017) dapat dikatakan bahwa kampanye dengan narasi yang berulang-ulang akan membentuk preferensi isu 
yang tercipta di media sosial pasangan calon tersebut dengan mencerminkan isu mengenai ekonomi merupakan preferensi politik kedua pasangan calon dalam kampanye pilkada melalui media sosial Facebook dan Twitter..

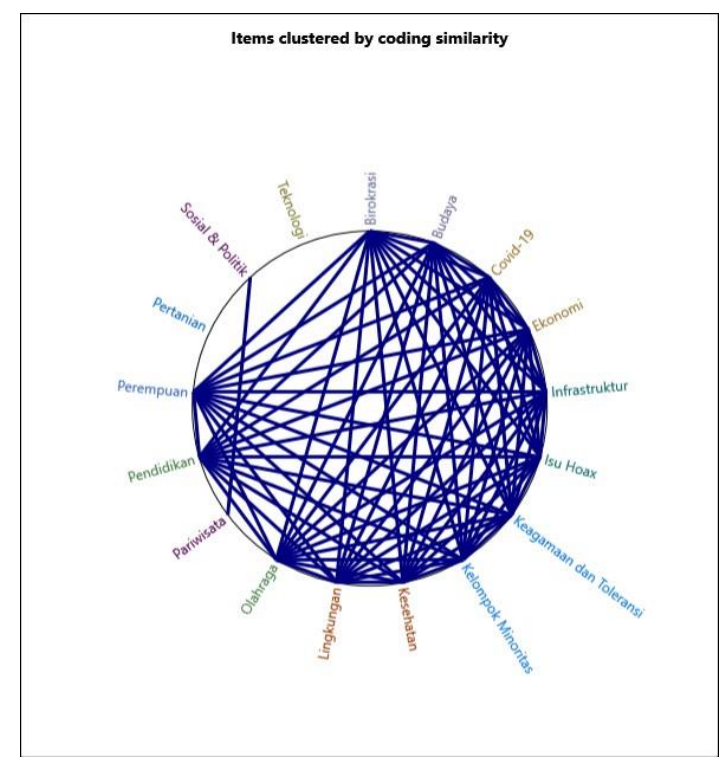

Gambar 1. Keterkaitan Isu Kampanye Pradi-Afifah di Media Sosial Sumber: Data diolah penulis

Kemudian dalam melihat keterkaitan isu kampanye satu sama lain, rekaman percakapan narasi pada media sosial masing-masing pasangan calon didapati temuan yang berbeda. Temuan tersebut ditunjukan oleh gambar 1 dan gambar 2. Sebagaimana gambar 1 menunjukan tentang keterkaitan masing-masing isu kampanye Pradi-Afifah di media sosial yang menunjukan bahwa terdapat dua isu kampanye yang tidak saling berkaitan satu sama lain yakni isu pertanian dan teknologi. Terdapat dua alasan dimana isu kampanye pasangan calon nomor urut 1 dinilai tidak terkait satu sama lain. Pertama, hal tersebut dikarenakan bahwa pasangan calon Pradi-Afifah tidak memiliki concern program kebijakan pertanian dan teknologi dalam kampanyenya. Sehingga tawaran program mengenai kebijakan dari dua indikator tersebut jarang atau tidak pernah dinarasikan di media sosial baik itu Facebook dan Twitter. Kedua, indikator isu kampanye pariwisata hanya berkaitan dengan indikator sosial dan politik. Hal tersebut dikarenakan kurang adanya tawaran program mengenai pariwisata secara kongkrit yang dinarasikan di media sosial. Sehingga isu kampanye pariwisata hanya ditandai sebagai upaya untuk menarik dukungan dari beberapa kelompok sosial dan politik di Kota Depok. 


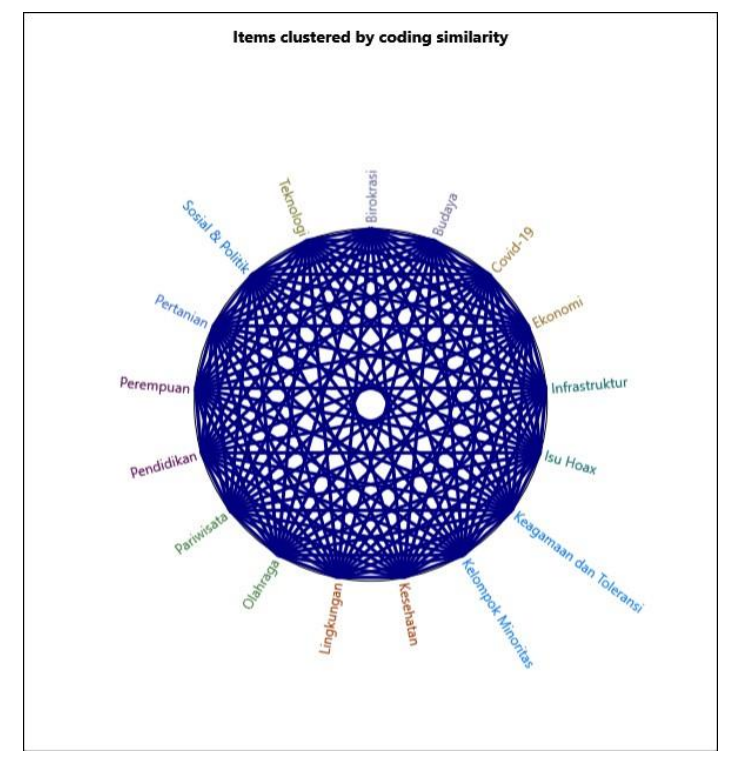

Gambar 2. Keterkaitan Isu Kampanye Idris-Imam di Media Sosial Sumber: Data diolah penulis

Berbeda dengan pasangan calon Pradi-Afifah, isu kampanye pasangan calon Idris-Imam dinilai lebih tebal dan berkaitan satu sama lain. Sebagaimana gambar 2 yang menjelaskan mengenai keterkaitan isu kampanye pada pasangan calon nomor urut 2 tersebut. Keterkaitan isu kampanye satu sama lain di media sosial menjelaskan temuan bahwa isu kampanye yang dominan pada pasangan calon tersebut yakni isu ekonomi, infrastruktur, dan sosial \& politik bersifat tidak otonom. Misalnya, program Kartu Depok Sejahter (KDS) yang kerap ditawarkan Idris-Imam melalui narasinya di media sosial, memiliki irisan dan korelasi dengan isu kampanye lainnya; 1) pelayanan kesehatan gratis (kesehatan); 2) bantuan pendidikan siswa dan juga bagi mahasiswa berprestasi (pendidikan); 3) jaminan pangan (pangan dan pertanian); 4) bantuan renovasi rumah (pembangunan dan infrastruktur), bantuan lanjut usia dan disabilitas (kelompok lansia dan minoritas), dan pelatihan keterampilan, bantuan usaha, dan penyaluran kerja (ekonomi) (lihat Megapolitan Kompas, 2020)

\section{Respon Warga Internet Sebagai Bentuk Partisipasi Digital}

Partisipasi politik secara digital yang menurut Lilleker \& Koc-Michalska (2017) merupakan kelanjutan dari partisipasi politik yang selama ini berbentuk tradisional. Partisipasi dalam dunia digital menunjukan respon keberpihakan terhadap komunikasi politik yang diciptakan oleh organisasi kampanye setiap pasangan calon. Partisipasi dalam dunia digital terutama di media sosial juga dapat menciptakan pembicaraan politik terhadap beberapa isu yang berorientasi secara publik. Maka dalam mengukur keterlibatan warga internet, partisipasi politik secara digital dinilai sangat diperlukan. Hal ini guna melihat sebaran penting isu yang dinarasikan oleh kedua pasangan calon di pemilihan kepala daerah Kota Depok 2020. Selain itu, respon warga internet juga menjadikan tolak ukur efektivitas penggunaan media sosial dalam berkampanye. Kampanye yang dilakukan oleh para politisi di dunia digital dapat menilai reaksi publik terhadap komunikasi politik yang dilakukan sebagai isyarat informal untuk menilai opini publik (Jungherr, 2016). Pandemi Covid-19 memudahkan para warga negara selaku pemilih untuk mengakses berbagai informasi yang berkaitan dengan kontestasi pilkada, termasuk di Kota Depok. Maka dari itu, penulis mencoba melihat besaran respon atas isu kampanye di media sosial dari kedua pasangan calon.

Beberapa penjelasan mengenai respon atas isu kampanye diklasifikan oleh penulis melalui tiga jenis yakni positif, netral, dan negatif. Respon positif dijelaskan sebagai bentuk dukungan, sikap setuju, dan keberpihakan kepada pasangan calon atas isu kampanye yang dinarasikan. Kemudian respon netral dicirikan dengan berupa pertanyaan mengenai isu 
kampanye yang dinarasikan, atau tawaran solusi atas permasalahan, serta komentar yang menunjukan ketidakberpihakan namun juga tidak menjatuhkan pasangan calon lainnya. Sementara itu respon negatif merupakan kebalikan dari bentuk respon positif seperti bentuk tidak mendukung, sikap tidak setuju, dan ketidakberpihakan kepada pasangan calon atas isu kampanye yang dinarasikan. Dari penjelasan tersebut, penelitian ini memiliki temuan yang berbeda pada kedua pasangan calon. Pradi-Afifah menjadi pasangan calon yang lebih memiliki respon positif dibandingkan dengan pasangan calon Idris-Imam di setiap isu kampanye pada kedua media sosial yang digunakan (Facebook dan Twitter). Lebih lanjut, temuan ini dijelaskan pada grafik 3 dan grafik 4.

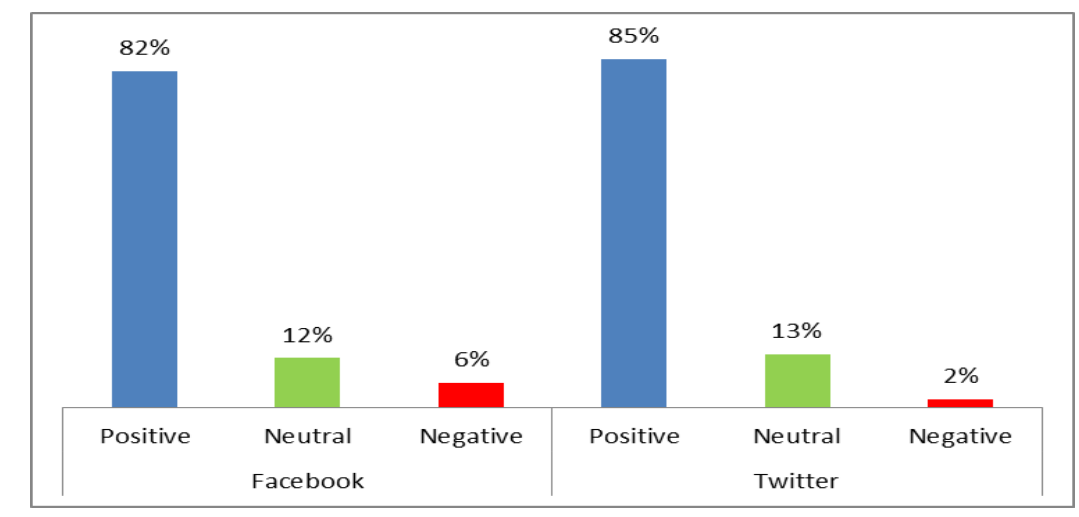

\section{Grafik 3. Respon Rata-Rata Warga Internet di Media Sosial Pradi-Afifah Sumber: Data diolah penulis}

Grafik 3 menunjukan bahwa bahwa Pradi-Afifah memiliki respon positif yang begitu dominan atas isu kampanye di media sosial yakni Facebook sebesar 82\% dan Twitter sebesar $85 \%$. Sementara itu komentar yang bersifat netral di masing-masing media sosial tersebut hampir serupa yakni berkisar sebesar 12\% di Facebook dan sebesar 13\% di Twitter. Ada pun besaran komentar negatif tertinggi terhadap Pradi-Afifah terdapat pada media sosial Facebook sebesar 6\%. Dari grafik 3 tersebut didapati bahwa respon rata-rata melalui komentar warga internet atas isu kampanye di media sosial memiliki respon positif sebesar $83,5 \%$, respon netral sebesar 7,5\%, dan respon negatif sebesar 4\%. Respon melalui komentar warga internet di media sosial ini menunjukan bahwa partisipasi digital terhadap isu kampanye Pradi-Afifah lebih banyak didominasi dengan narasi dukungan warga internet.

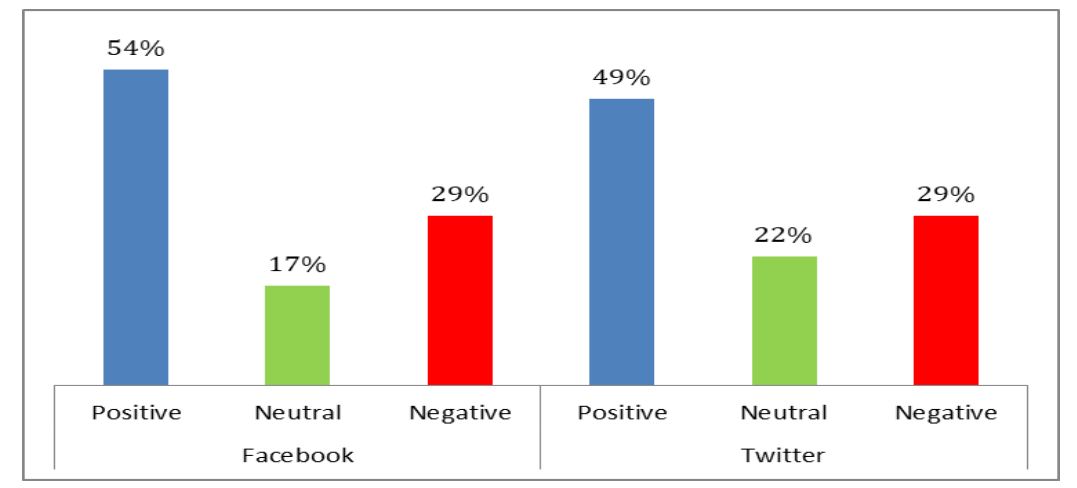

Grafik 4. Respon Rata-Rata Warga Internet di Media Sosial Idris-Imam Sumber: Data diolah penulis

Berbeda dengan grafik 3 yang menunjukan bentuk pertisipasi digital melalui respon komentar terhadap pasangan Pradi-Afifah. Grafik 4 menunjukan respon komentar terhadap pasangan Idris-Imam. Temuan pada media sosial Idris-Imam atas respon terhadap isu kampanye dinilai masih didominasi oleh komentar positif warga internet. Namun hal ini juga 
diiringi dengan tingginya respon negatif yang diterima di media sosial Idris-Imam dibanding dengan media sosial Pradi-Afifah. Respon positif warga internet mencapai persentase tertinggi di antara kedua media sosial tersebut, yakni ada pada media sosial Facebook sebesar 54\%. Sedangkan respon negatif didapati oleh Idris-Imam di atas $20 \%$ pada kedua media sosial tersebut, yakni Facebook dan Twitter yang sama-sama mencatatkan persentase sebanyak 29\%. Grafik 4 menjelaskan bahwa respon rata-rata komentar warga internet atas isu kampanye di media sosial Idris-Imam memiliki persentase yang berbeda-beda yakni respon positif sebesar $52,5 \%$, respon netral sebesar $19,5 \%$, dan respon negatif sebesar $29 \%$.

Temuan dari isu kampanye kedua pasangan calon menjelaskan tiga hal. Pertama, partisipasi digital oleh warga internet di kedua media sosial tersebut menjelaskan bahwa pasangan calon Pradi-Afifah lebih banyak mendapatkan dukungan positif. Hal ini dikarenakan Pradi Supriatna merupakan pejabat Wakil Walikota Depok yang mencalonkan diri, banyak warga internet yang merespon baik isu kampanye yang dinarasikan di media sosial. Terlebih pasangan Idris-Imam, keduanya dinilai merupakan pasangan yang diusung oleh partai penguasa di Kota Depok yakni Partai Keadilan Sejahtera (PKS), sehingga warga internet di media sosial lebih menginginkan perubahan dan pergantian pemerintahan Kota Depok dengan banyaknya respon dukungan kepada Pradi (Gerindra) dan Afifah (PDIP). Kedua, komentar berupa tagar \#benahidepok dan \#gerakanperubahan selalu menghiasi dan disematkan pada setiap kolom komentar isu kampanye di media sosial, terutama di media sosial pasangan calon Pradi-Afifah. Hal ini menunjukan bahwa narasi komentar-komentar tersebut dianggap mewakili pihak oposisi di Kota Depok meskipun Pradi Supriatna merupakan petahana pejabat Wakil Walikota Depok 2015-2020. Hal ini pula yang menunjukan partisipasi digital dengan narasi yang begitu positif dapat dibangun di setiap isu kampanye pada media sosial Pradi-Afifah, Ketiga, kehadiran sosok Afifah Alia yang merupakan representasi perempuan juga dinilai cukup mendorong partisipasi positif dari warga internet. Lebih lanjut, isu permasalahan pelecehan secara verbal yang dilakukan oleh calon Wakil Walikota Depok Imam Budi terhadap Afifah Alia, memunculkan reaksi dan dukungan positif terhadap Afifah Alia itu sendiri. Sehingga dukungan yang diterima tersebut dinilai telah meningkatkan respon positif warga internet terhadap isu kampanye PradiAfifah di media sosial.

\section{KESIMPULAN}

Penggunaan media sosial dalam Pilkada Kota Depok dinilai merupakan upaya untuk menghindari kerumunan disaat kampanye namun tetap tidak meninggalkan tujuan kampanye itu sendiri. Penyampaian narasi dalam setiap isu kampanye oleh masing-masing pasangan calon Wali Kota dan Wakil Wali Kota Depok dapat menentukan preferensi program kebijakan apabila telah terpilih. Dalam penelitian ini, perbandingan isu kampanye di Pilkada Kota Depok menunjukan temuan yang berbeda dimana pada pasangan nomor urut 1 Pradi-Afifah, memilik fokus program kebijakan di bidang kesehatan dan infrastruktur. Sementara itu pasangan nomor urut 2, Idris-Imam, isu kampanye di media sosial juga dinilai lebih merata dari pasangan nomor urut 1. Isu kampanye infrastruktur dan perekonomian menjadi preferensi isu dalam gelaran kampanye pasangan calon tersebut.

Diperlukan indikator penilaian dengan melihat respon warga internet dalam melihat bentuk partisipasi digital yang terbagi menjadi 3 jenis respon yakni positif, netral, dan negatif. Respon ini dilihat ketika warga internet menuliskan komentar terhadap isu kampanye yang dinarasikan oleh setiap pasangan calon di media sosial. Kedua media sosial seperti Facebook dan Twitter, dipilih karena merupakan media sosial yang banyak digunakan oleh warga internet. Kedua media sosial tersebut juga menunjukan platform digital yang diperuntukan dalam akses informasi Pilkada Kota Depok, termasuk yang digunakan oleh kedua pasangan calon. Walikota dan Wakil Walikota Depok 2020.

Namun, unggulnya bentuk partisipasi digital di media sosial tidak serta merta menjadikan pasangan calon tersebut meraih kemenangan dalam Pemilihan Kepala Daerah Kota Depok 2020. Temuan penelitian ini menjelaskan Pradi-Afifah mencatatkan rata-rata respon positif di media sosial 83,5\%, yang merupakan persentase yang lebih tinggi dari pasangan calon 
Idris-Imam 52,5\%. Namun secara perolehan suara Idris-Imam lebih unggul sebesar 55,54\% dibandingkan dengan perolehan suara Pradi-Afifah 44,46\% (Megapolitan Kompas, 2021). Ini juga menunjukan bahwa kendati adanya klausul kampanye PKPU Nomor 6 Tahun 2020 Pasal 58 dengan menyarankan penggunaan media sosial, tidak serta merta menjadi faktor determinan dalam membangun isu kampanye serta partisipasi digital, termasuk juga dalam memenangkan kontestasi Pemilihan Kepala Daerah di Kota Depok Tahun 2020. Ini sekaligus membantah temuan Lilleker \& Koc-Michalska (2017) yang juga menyatakan bahwa partisipasi secara digital dapat dijadikan sebagai modal untuk memobilisasi dalam bentuk partisipasi politik di dunia nyata secara lebih lanjut. Karena partisipasi politik melalui pemungutan suara beserta keberpihakannya tidak begitu dapat dibuktikan dalam temuan penelitian ini. Kendati isu dalam kampanye dinarasikan secara berulang, hal ini tidak dapat berkorelasi lebih lanjut mengenai penentuan preferensi isu publik dalam Pilkada di Kota Depok.

\section{UCAPAN TERIMAKASIH}

- Ucapan terimakasih ditujukan kepada seluruh anggota dari Relawan Komite Independen Sadar Pemilu (KISP) yang telah memantau penyelenggaraan pemilihan kepala daerah di Kota Depok pada Tahun 2020.

- Ucapan terimakasih ditujukan kepada jajaran penyelenggara pemilihan di Kota Depok dalam hal ini Komisi Pemilihan Umum (KPU) Kota Depok dan Badan Pengawas Pemilu (Bawaslu) Kota Depok yang telah membantu jalannya proses pemantauan Pilkada di Kota Depok.

\section{REFERENSI}

Alihodžić, S. (Ed.). (2016). Risk Management In Election. International Institute for Democracy and Electoral Assistance (International IDEA).

Andriadi, F. (2017). Partisipasi Politik Virtual. RMB00KS.

Baroya, A. (2020). "Pilkada Bersyarat" Pilkada di Tengah Pandemi. In S. Munawar (Ed.), Pilkada di Masa Pandemi (pp. 10-18). Penerbit Lingkaran.

Budiardjo, M. (2008). Dasar-Dasar Ilmu Politik Edisi Revisi (Edisi Revi). Gramedia Pustaka Utama.

Chester, J., \& Montgomery, K. C. (2017). The Role of Digital Marketing in Political Campaigns. Internet Policy Review, 6(4), 1-20. https://doi.org/http://dx.doi.org/10.14763/2017.4.773

Chilcote, R. H. (2016). Teori Perbandingan Politik. PT RajaGrafindo Persada.

Cosmopolitan. (2020). 4 Media Sosial yang Paling Sering Digunakan Warga Indonesia. Cosmopolitan.Co.Id. https://www.cosmopolitan.co.id/article/read/6/2020/20831/4media-sosial-yang-paling-sering-digunakan-warga-indonesia

Creswell, J. (2016). Research Design: Pendekatan Metode Kualitatif, Kuantitatif, dan Campuran. PUSTAKA PELAJAR.

Diana, S. N. (2017). Identifikasi Pengguna Media Sosial yang Berpengaruh Berdasarkan Graph dengan Metode Social Network Analysis.

Hagar, D. (2014). Campaigning Online: Social Media in the 2010 Niagara Municipal Elections. Canadian Journal of Urban Research, 23(1), 23(1), 74-98.

Jansen, M. J. (2017). Social Media and Political Campaigning: Changing Terms of Engagement? The International Journal of Press/Politics, 22(1), 23-42. https://doi.org/10.1177/1940161216673196

Jungherr, A. (2016). Four Functions of Digital Tools in Election Campaigns: The German Case. The International Journal of Press/Politics, 21(3), 358-377. https://doi.org/10.1177/1940161216642597

Kholid, A., \& Nurmandi, A. (2015). Media Sosial dan Partisipasi Politik Mahasiswa selama Masa Pemilihan Presiden 2014. Jurnal Ilmu Pemerintahan \& Kebijakan, 2(1), 2015. http://dx.doi.org/10.18196/\%0Ajgpp.2015.0025

Kim, S. C. (2020). South Korea's 2020 Election Amid COVID-19. East Asian Policy, 12(03), 49-62. 
Kompas. (2020). KPU Terima Surat Tugas dari Gugus Tugas Covid-19: Tahapan Pilkada Boleh Dilanjutkan.

https://nasional.kompas.com/read/2020/05/27/16444041/kpu-terima-surat-dari-

gugus-tugas-covid-19-tahapan-pilkada-boleh-dilanjutkan?page=all

Kumparan. (2020). Pemerintah-DPR-KPU Sepakat Pilkada Serentak Tetap Desember 2020. Kumparan.Com. https://kumparan.com/kumparannews/pemerintah-dpr-kpu-sepakatpilkada-serentak-tetap-desember-2020-1tUr0UKo0t2/full

Lee, S. H. (2017). Digital Democracy in Asia The Impact of the Asian Internet on Political Participation. Journal of Information Technology \& Politics, 14(1), 62-82. https://doi.org/https://doi.org/10.1080/19331681.2016.1214095

Lilleker, D. G., \& Koc-Michalska, K. (2017). What Drives Political Participation? Motivations and Mobilization in a Digital Age. Political Communication, 34(1), 21-43.

Megapolitan Kompas. (2020). Idris-Imam Janji Keluarkan Kartu Depok Sejahtera di Akhir Debat Pilkada, Apa Itu? Kompas.Com. https://megapolitan.kompas.com/read/2020/11/22/17581591/idris-imam-janjikeluarkan-kartu-depok-sejahtera-di-akhir-debat-pilkada?page=all

Megapolitan Kompas. (2021). KPU Depok Tetapkan Idris-Imam Wali Kota dan Wakil Wali Kota Terpilih.

Kompas.Com. https://megapolitan.kompas.com/read/2021/01/21/14332041/kpu-depok-tetapkanidris-imam-wali-kota-dan-wakil-wali-kota-terpilih

Nimmo, D. (2010). Komunikasi Politik (5th ed.). PT Remaja Rosdakarya.

Paisley, W. J., \& Rice, R. E. (1981). Public Communication Campaigns. Sage Publications.

Permana, D. S. (2020). Pemilihan Wali Kota dan Wakil Wali Kota Depok Tahun 2020 (Evaluasi, Progress, dan Potensi Pelanggaran). Sharing Bareng KISP.

Purbolaksono, A. (2021). Menimbang Manajemen Risiko Penyelenggaraan Pemilu dan Pilkada 2024.

Ristyastuti, M. P., \& Rofii, M. S. (2021). Analisis Naratif Kebijakan Penyelenggaraan Pilkada Saat Pandemi Covid-19 di Indonesia. Jurnal Ilmu Pengetahuan Sosial, 8(2), 47-53.

RNZ. (2020). How Singapore Carried Out Its Covid-19 Election. Rnz.Co.Nz. https://www.rnz.co.nz/programmes/the-detail/story/2018760358/how-singaporecarried-out-its-covid-19-election

Roger, E. M., \& Storey, J. D. (1987). Communication Campaign. In C. R. Berger \& S. H. Chaffee (Eds.), Handbook of Communication Science. Sage.

Rusnaedy, Z., \& Purwaningsih, T. (2018). Keluarga Politik Yasin Limpo Pada Pemilihan Kepala Daerah di Kabupaten Gowa Tahun 2015. Jurnal Politik, 3(2), 301-322. https://doi.org/10.7454/jp.v3i2.116

Rusnaedy, Z. (2020). Dinasti Politik di Aras Lokal. Yogyakarta: Deepublish Publisher

Sakbani, Y. (2020). Urgensi Manajemen Risiko Pemilu pada Pilkada 2020 di Tengah Pandemi Covid 19 (Studi Perlindungan Hak Pilih Warga Masyarakat). Jurnal Wacana Politik, 5(2), 124-135.

Surbakti, R. (2010). Memahami Ilmu Politik. PT. Gramedia Widiasarana Indonesia.

Theocharis, Y. (2015). The Conceptualization of Digitally Networked Participation. Social Media+Society, 1(2), 1-14. https://doi.org/https://doi.org/10.1177/2056305115610140

Vaccari, C., Valeriani, A., \& Barberá, P. (2013). Social Media and Political Communication: A survey of Twitter Users During the 2013 Italian General Election. Rivista Italiana Di Scienza Politica, 43(3), 325-355. 